\title{
抵抗と揚力の働く投射体の最大投射角*
}

\section{The Maximum Projection Angle of a Projectile under Drag and Lift}

\author{
Kazuhiro TSUBOI ${ }^{* 1}$ \\ ${ }^{* 1}$ Ibaraki Univ. Dept. of Intelligent Systems Engineering, \\ Naka-narusawa 4-12-1, Hitachi, 316-8511 Japan
}

We investigate the maximum projection angle of a projectile under drag and lift with constant coefficients. The equation of motion for a particle under drag and lift proportional to the speed is derived from that with the quadratic law of drag and lift. The linearized equation provides the second order perturbed solution of the maximum projection angle. Comparing the perturbed solution with numerical ones calculated from the equation with the quadratic drag and lift, the following results are obtained: (1) Both the drag and lift decrease the maximum projection angle; (2) The decrease due to lift is larger than that due to drag; (3) The maximum projection angle has a concave curve according to drag while it has a convex shape for lift; (4) The second-order formulae for drag and lift give a good approximation to the maximum projection angle.

Key Words : Sports Engineering, Nonlinear Dynamics, Modeling, Particle Dynamics, Lift and Drag, Projection Angle, The Maximum Distance, Perturbed Solution, Approximate Formulae

\section{1. 緒言}

スポーツ競技で見られる放物運動は大きく 2 種類に分類される(1). ひとつは人体そのものが投射体となる場合 であり，他は人体以外の投射体を使用寸るものである．前者の例としては陸上競技の跳躍種目（走り幅跳び，三 段跳びや走り高跳びなど) やスキーのジャンプ競技などを挙げることができる.一方，陸上競技の投てき種目（砲 丸投げ，やり投げ，ハンマー投げなど）をはじめとして多くの球技（野球，サッカー，ゴルフなど）が後者に該 当する．そして，後者では投射体に推進力を与えるために人体が大きな役割を担っている.

これらのスポーツ競技のなかでも投射体の飛距離を競う競技においては投射体の種類に因らず放物運動に対す る力学的特性の把握が重要になる.特に一定の初速度の下で投射体を最も遠くまで飛ばすことのできる初速角(最 大投射角）に関する知識がその基礎を与えることは容易に理解できる.

重力以外に外力が働かない投射体の最大投射角が $45^{\circ}$ となることは周知であるが, 前述したスポーツ競技の多 くはこのような大きな角度を利用していない，例えば，砲丸投げでは $30^{\circ} \sim 40^{\circ}$ 付近，走り幅跳びでは $20^{\circ} \sim$ $30^{\circ}$ 付近である. また, ゴルフのドライバー・ショットのボール打ち出し角は $10^{\circ}$ 付近であることも古くから知 られた事実である(2)(3).

これらのうちで砲丸投げの投射角や走り幅跳びの踏切角に関しては，それらが助走を伴った投射による放物運 動である点が本質的であり，その効果を投射モデルに導入することによって上述した範囲が最大投射角となるこ とが説明できる. その際, 投射モデルとして初速度を初速角の関数として与えるモデル(4)(5)や助走の効果を変数と して組み込んだモデル(6)(7)が提案されている.なお,これらの例においては投射体に働く空気力は抵抗のみであり， その抵抗も全飛距離に対して高々数\%の影響しか与えないことから空気力の最大投射角への効果は実際上無視で きる程度である。

\footnotetext{
* 原稿受付 2012 年 3 月 4 日

*1 正員, 茨城大学工学部（干316-8511 茨城県日立市中成沢町 4-12-1）

E-mail: ktsuboi@mx.ibaraki.ac.jp
} 
一方，例えばゴルフのドライバー・ショットには助走の効果は含まれないので，空気力の効果によって前述し た打ち出し角が説明されるべきである.ゴルフをはじめとして多くの球技で使用されるボールは飛翔時に回転運 動をしており，これによって発生する揚力が飛距離を大きく伸ばす要因となる. しかしながら, 回転するボール に働く空気力の測定は容易ではなく, その結果としてボールに㗢く空気力についてはいまだに不明の点が多い(8)(9). しかも飛翔中のボールに働く空気力はボール形状や回転数によって複雑に変化する非定常力であり, この事実も またボールに働く空気力の解明を難しくしている.

多くのスポーツ競技で見られる投射体のレイノルズ数は Re 〜 $10^{5}$ のオーダ(1)であり，この範囲では抵抗，揚 力ともに投射体の速度の自乗に比例すると考えてよい. この比例係数からそれぞれ抵抗係数と揚力係数が定義さ れ，投射体の空力特性は一般にはこれらの值によって特徴付けられる. しかしながら，上述したように飛翔中の ボールに対する抵抗係数や揚力係数は定数とはならず回転数などのパラメータに依存する. このように実際のボ ールに働く空気力は複雑であるため, その軌道予測には主にシミュレーションが用いられる(3)(10).

その一方で, 抵抗係数や揚力係数が一定となる投射体に対しても，その軌道を解析的に求めることはできてお らず，その結果として最大投射角についてはほとんどわかっていないようである. 速度の自乗に比例する抵抗が 働く質点の最大投射角に関しては, 抵抗が大きいほど最大投射角が小さくなることが指摘されている ${ }^{(11)}$. そして, 実際に運動方程式から最大投射角を求める試みがいくつか行われてはいるが，実際に最大投射角を抵抗係数の関 数として求めることは出来ていない(12)(13). さらに, 揚力の効果も含んだ質点の最大投射角については著者の調心゙ た限りでは全く結果が知られていないようである.

本論文では投射体の最大投射角に対する抵抗と揚力の影響について調べ，それによって最大投射角の定性的特 徵を明らかにすることを試みる．そのために抵抗係数と揚力係数が一定の場合の質点に対する最大投射角を考察 する. その際，速度の自乗に比例する空気力が働く質点の運動方程式では，その非線形性のために解析的な形で 最大投射角を求めることができない. そこで, 投射体の速さを空力係数に繰り込むことで運動方程式を線形化し, 速度に比例した空気力に対寸る運動方程式を導く. 線形化した運動方程式の摂動解として最大投射角を抵抗係数 と揚力係数の関数として陽に求め, その解より最大投射角の定性的特徵を明らかにする. さらに，運動方程式の 数值解と比較することで求めた摂動解を評価するとともに投射体の最大投射角に対する空気力の効果を検証する.

\section{2. 運動方程式と線形化}

投射時の投射体の重心位置を座標原点とし，鉛直上向きに $y$ 軸をとる．投射体の初速度べクトルと $y$ 軸が作る 平面を考え，この平面内で水平方向に $x$ 軸をとる. 以下では投射体はこの $x-y$ 平面内で 2 次元運動するものと仮 定する。

速度の自乗に比例する抵抗と揚力がともに投射体に働く場合, 投射体の重心の運動方程式と初期条件は次式で 与えられる。

$$
\begin{aligned}
& m \frac{d u}{d t}=-k q u-l q v, \quad m \frac{d v}{d t}=-k q v+l q u-m g, \\
& u(0)=q_{i} \cos \theta \equiv u_{i}, v(0)=q_{i} \sin \theta \equiv v_{i}, x(0)=y(0)=0 .
\end{aligned}
$$

ここで $(x, y)$ および $(u, v)$ は投射体重心の位置ベクトルと速度ベクトルで $q^{2}=u^{2}+v^{2}$ とする.また, $m$ および $g$ は投射体の質量と重力加速度， $q_{i}$ と $\theta$ はそれぞれ初速度と初速角（投射角）である.

式（1）に含まれる $k$ と $l$ は次式で定義される抵抗と揚力の比例定数である.

$$
k=\frac{1}{2} \rho \frac{\pi}{4} d^{2} C_{D}, \quad l=\frac{1}{2} \rho \frac{\pi}{4} d^{2} C_{L} .
$$

ただし $\rho$ は空気密度， $C_{D}$ と $C_{L}$ は無次元の抵抗係数と揚力係数である. また， $d$ は投射体の代表径であり，ここ ではボールのような円形断面をもつ投射体を念頭に置いている. 
ここで式（1）と式（2）の無次元化を考える. 放物運動に特徵的な物理量として重力加速度 $g$ と初速度 $q_{i}$ を採 ると各物理量は以下のように無次元化できる.

$$
u=u^{*} q_{i}, \quad v=v^{*} q_{i}, \quad q=q^{*} q_{i}, \quad t=t^{*} \frac{q_{i}}{g}, \quad x=x^{*} \frac{q_{i}^{2}}{g}, \quad y=y^{*} \frac{q_{i}^{2}}{g} .
$$

ここで*の付いた量は無次元量である.

このとき式（1）と式（2）はそれぞれ

$$
\begin{aligned}
& \frac{d u^{*}}{d t^{*}}=-\varepsilon_{D} q^{*} u^{*}-\varepsilon_{L} q^{*} v^{*}, \quad \frac{d v^{*}}{d t^{*}}=-\varepsilon_{D} q^{*} v^{*}+\varepsilon_{L} q^{*} u^{*}-1, \\
& u^{*}(0)=\cos \theta \equiv u_{i}^{*}, v^{*}(0)=\sin \theta \equiv v_{i}^{*}, x^{*}(0)=y^{*}(0)=0,
\end{aligned}
$$

と書き直すことができる.ここで， $\varepsilon_{D}$ と $\varepsilon_{L}$ はそれぞれ

$$
\varepsilon_{D}=\frac{k q_{i}^{2}}{m g}, \quad \varepsilon_{L}=\frac{l q_{i}^{2}}{m g},
$$

で定義される無次元パラメータであり，ここでは de Mestre にしたがってそれぞれを重量抵抗比（drag-to-weight ratio), 重量揚力比（lift-to-weight ratio）と呼ぶことにする. なお，代表的なスポーツ競技の重量抵抗比はおおむ ね $0.01 \leq \varepsilon_{D} \leq 1$ の範囲 ${ }^{(1)}$ にあり，これらのパラメータによる摂動解を考える根拠となる.

式 (4) は非線形方程式であり，その解を陽に求めることはできない，そこで，ここでは次式で定義されるパラ メータ $\alpha$ と $\beta$ を考え，これらを一定と仮定することで運動方程式の線形化を行う.

$$
\alpha \equiv \varepsilon_{D} q^{*} \approx \varepsilon_{D}, \quad \beta \equiv \varepsilon_{L} q^{*} \approx \varepsilon_{L}
$$

このとき，運動方程式（4）は以下の形に線形化される.

$$
\frac{d u^{*}}{d t^{*}}=-\alpha u^{*}-\beta v^{*}, \quad \frac{d v^{*}}{d t^{*}}=-\alpha v^{*}+\beta u^{*}-1 .
$$

すなわち，式（4）において $q^{*}=1$ のとき，式中の $\varepsilon_{D}$ と $\varepsilon_{L}$ は式（8）の $\alpha$ と $\beta$ にそれぞれ一致する.このことから 式（7）の近似は投射後も投射体の速さが初速度と同じ值（i.e. $q=q_{i}$ ）をもつことを意味する.

\section{3. 線形問題による定性的評価}

\section{$3 \cdot 1$ 軌道}

運動方程式（8）は複素数を用いることで，その扱いが簡単になる. なお，ここでは簡単のため無次元量を表わ す*は省略するが，す心゙ての物理量は無次元量とする.

まず，式（8）から終端速度 $\left(u_{\infty}, v_{\infty}\right)$ は次式となる.

$$
u_{\infty}=\frac{\beta}{\alpha^{2}+\beta^{2}}, \quad v_{\infty}=-\frac{\alpha}{\alpha^{2}+\beta^{2}} .
$$

これらの終端速度を使って

$$
U=u-u_{\infty}, \quad V=v-v_{\infty},
$$

を定義すると式（8）の第２式の重力項が消えて次の同次方程式になる.

$$
\frac{d U}{d t}=-\alpha U-\beta V, \quad \frac{d V}{d t}=\beta U-\alpha V .
$$


式（11）に対して

$$
W=U+i V, \quad \gamma=\alpha+i \beta,
$$

で定義される複素数の速度 $W$ とパラメータ $\gamma$ を導入すると式（11）は簡単に

$$
\frac{d W}{d t}=-\bar{\gamma} W
$$

と書ける．ここで上付きの－は複素共役を表す.

式（13）から速度 $W$ は

$$
W=W_{i} \exp (-\bar{\gamma} t)
$$

で与えられる，だたし， $W_{i}$ は初期条件（5）から

$$
W_{i}=U_{i}+i V_{i}=u_{i}+i v_{i}-\left(u_{\infty}+i v_{\infty}\right) \equiv w_{i}-w_{\infty} .
$$

ここで $w_{i}=u_{i}+i v_{i}$ および $w_{\infty}=u_{\infty}+i v_{\infty}$ である.

位置は速度 $W$ の定義（12）から

$$
Z \equiv \int_{0}^{t} W d t=\int_{0}^{t}(U+i V) d t=x+i y-\left(u_{\infty}+i v_{\infty}\right) t \equiv z-w_{\infty} t .
$$

ただし $z=x+i y$ とする. 一方，初期条件（5）を用いると式（14）からは

$$
Z=\int_{0}^{t} W d t=\int_{0}^{t} W_{i} \exp (-\bar{\gamma} t) d t=\frac{W_{i}}{\bar{\gamma}}(1-\exp (-\bar{\gamma} t))
$$

が得られる。

以上より運動方程式（8）の解の複素数表示は

$$
z=w_{\infty} t+\frac{W_{i}}{\bar{\gamma}}(1-\exp (-\bar{\gamma} t))
$$

となり，これよりそれぞれの位置座標が時間の関数として以下のように求まる.

$$
\begin{aligned}
& x=\operatorname{Re}(z)=u_{\infty} t+\frac{\alpha U_{i}-\beta V_{i}}{\alpha^{2}+\beta^{2}}(1-\exp (-\alpha t) \cos \beta t)+\frac{\alpha V_{i}+\beta U_{i}}{\alpha^{2}+\beta^{2}} \exp (-\alpha t) \sin \beta t, \\
& y=\operatorname{Im}(z)=v_{\infty} t+\frac{\alpha V_{i}+\beta U_{i}}{\alpha^{2}+\beta^{2}}(1-\exp (-\alpha t) \cos \beta t)-\frac{\alpha U_{i}-\beta V_{i}}{\alpha^{2}+\beta^{2}} \exp (-\alpha t) \sin \beta t .
\end{aligned}
$$

特に $\beta=0$ の場合には式（16）と（17）は

$$
\begin{aligned}
& x=\frac{u_{i}}{\alpha}(1-\exp (-\alpha t)), \\
& y=\frac{1}{\alpha}\left\{\left(v_{i}+\frac{1}{\alpha}\right)(1-\exp (-\alpha t))-t\right\},
\end{aligned}
$$

となり既知の結果と一致する ${ }^{(14)}$. 


\section{$3 \cdot 2$ 摄動解の導出}

最大投射角を求めるためには, 式（16）と（17）からボールの落下位置 $L$ を求める必要がある. これは式 (17) で $y=0$ となる時刻 (落下までの時間) $T$ をまず求め, これを式 (16) に代入することで得られる. しかしながら, この手順で落下位置 $L$ を陽に求めることは困難であるため, 以下ではパラメータ $\alpha$ と $\beta$ に関する摂動展開を用い て落下位置 $L$ の摂動解を求める.

まず，式（15）を皇について形式的に 2 次まで展開する.

$$
z_{p}=t\left(w_{i}-\frac{1}{2} i t\right)-\frac{1}{2} \bar{\gamma} t^{2}\left(w_{i}-\frac{1}{3} i t\right)+\frac{1}{6} \bar{\gamma}^{2} t^{3}\left(w_{i}-\frac{1}{4} i t\right)+\mathrm{O}\left(|\gamma|^{3}\right) .
$$

式（20）の展開に対して落下時間 $T$ は次の方程式の解として求まる.

$$
\left.y(T) \approx \operatorname{Im}\left(z_{p}\right)\right|_{t=T}=0 .
$$

この方程式に対して付録 $\mathrm{A} \cdot 2$ に示した解の公式を用いる. その際，上式の $y$ と $T$ 公式中の $f$ と $\xi$ それぞれ 対応させ， $c=0$ として落下時刻 $T$ の第 2 次までの摂動解を求めると

$$
T=2 v_{i}-\alpha \frac{2}{3} v_{i}^{2}+\beta 2 u_{i} v_{i}+\alpha^{2} \frac{4}{9} v_{i}^{3}-\alpha \beta \frac{8}{3} u_{i} v_{i}^{2}+\beta^{2} 2\left(u_{i}^{2} v_{i}-\frac{1}{3} v_{i}^{3}\right),
$$

が得られる.

これより落下位置 $L$ は

$$
L=\left.x(T) \approx \operatorname{Re}\left(z_{p}\right)\right|_{t=T},
$$

として求めることができるので，付録 $\mathrm{A} ・ 1$ の展開公式において $f$ とににそれぞれ $x$ と $T$ を対応させて

$$
L=2 u_{i} v_{i}-\alpha \frac{8}{3} u_{i} v_{i}^{2}+\beta \frac{2}{3} v_{i}\left(3 u_{i}^{2}-v_{i}^{2}\right)+\alpha^{2} \frac{28}{9} u_{i} v_{i}^{3}-\alpha \beta \frac{4}{3} v_{i}^{2}\left(u_{i}^{2}-v_{i}^{2}\right)+\beta^{2} 2 u_{i} v_{i}\left(u_{i}^{2}-v_{i}^{2}\right),
$$

となる.

式（5）の初期条件より式（22）の右辺は $\theta$ の関数となるので， $L=L(\theta)$ に対する極值問題

$$
\frac{d L}{d \theta}=0
$$

の解として最大投射角 $\theta_{\text {max }}$ が決まる.

この場合には付録 $\mathrm{A} \cdot 2$ の解の公式において $f=d L / d \theta, \xi=\theta, c=0$ とおくことで, 最大投射角の第 2 次まで の摂動解が得られる.

$$
\theta_{\max }=\frac{\pi}{4}-\frac{\sqrt{2}}{6} \alpha-\frac{\sqrt{2}}{4} \beta+\frac{1}{9} \alpha^{2}+\frac{1}{6} \alpha \beta-\frac{1}{8} \beta^{2}
$$

ただし，角度の単位は radian である。

式(24)から最大投射角に関して以下の性質が予想できる.

（1）第 1 次項の係数の符号より，抵抗と揚力はともに最大投射角を減少させる.

(2) 第 1 次項の係数より，揚力の方が抵抗より最大投射角の減少に対する影響は大きい. 特に線形問題におい て空気力の効果が十分小さいときには揚力の減少率は抵抗の 1.5 倍 $(=(\sqrt{2} / 4) /(\sqrt{2} / 6))$ である.

（3）第 2 次項の係数の符号から，最大投射角は抵抗に対して下に凸，揚力に対しては上に凸の曲線となる. 


\section{4. 結果の検証}

\section{$4 \cdot 1$ 摂動解の評価}

前章で導いた捸動解の適用範囲を確認寸るために数值解との比較を行った．数值解は式（8）を Runge-Kutta 法 で数值積分することで求めた，その際，時間刻みは $\Delta t=10^{-3}$ とし，初速角を $\pi / 4$ から $\pi / 100\left(=1.8^{\circ}\right)$ 刻みで減少さ せ，それぞれの初速角の落下位置 $L$ から最大となる角度を決めた。

揚力が働かない場合の抵抗による最大投射角 $\theta_{\max }$ の変化を図 1 に示寸. 破線と実線はそれぞれ第 1 次と第 2 次 までの摂動解である. 図中の○が数值解であり， $\alpha \sim 1.0$ で最大投射角は $35^{\circ}$ 程度まで減少している. 数值解と 摂動解との比較から第 1 次の摂動解は $\alpha \leq 0.1$ 程度, 第 2 次の解では $\alpha \leq 0.5$ 程度の範囲で有効であることがわかる. また，数值解は $\alpha \leq 1.0$ の範囲で下に凸の曲線となっており，この傾向は第 2 次の摂動解と定性的に一致している ことが確認できる.

同様に，抵抗のない場合の最大投射角 $\theta_{\max }$ の揚力による変化を図 2 に示寸．図中で用いた記号の意味は図 1 と 同じである．抵抗の働かない投射体は現実には存在しないが，ここでは式（24）を検証するためにこの場合の結 果も求めた.

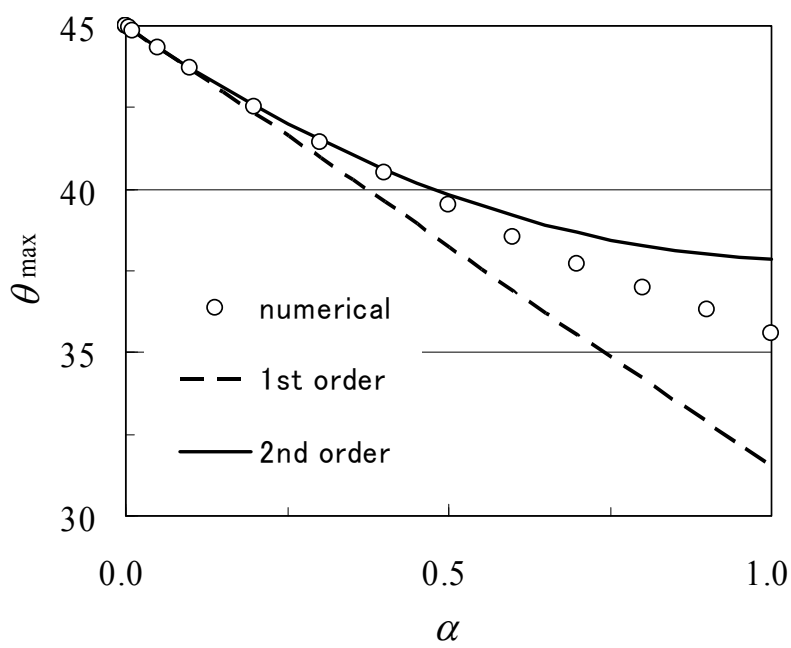

Fig. 1 The effect of linear drag to the maximum projection angle without lift $(\beta=0)$

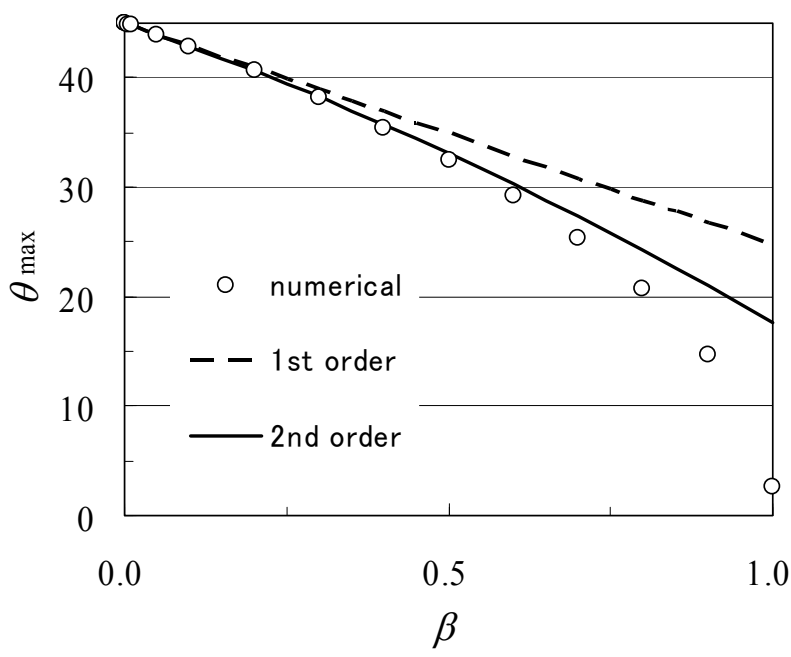

Fig. 2 The effect of linear lift to the maximum projection angle without drag $(\alpha=0)$ 
数值解の結果から，最大投射角は $\beta \leq 1.0$ の範囲で上に凸の曲線となっており，その結果として $\beta$ が大きくなる ほど最大投射角は急激に小さくなる．実際， $\beta=1.0$ で $\theta_{\max }=2.6^{\circ}$ まで減少していることがわかる．そして，この 傾向は第 2 次の摂動解と一致している. 数值解と摂動解の比較から揚力による変化も第 1 次までの解は $\beta \leq 0.2$ 程度, 第 2 次までの解は $\beta \leq 0.5$ 程度の範囲で有効である.

また， $\alpha=\beta$ のときの最大投射角の変化を図 3 に示寸．この場合の摂動解は式（24）より以下となる.

$$
\theta_{\max }=\frac{\pi}{4}-\frac{5 \sqrt{2}}{12} \alpha+\frac{11}{72} \alpha^{2}
$$

式 (25) の第 1 次までの解が図 3 の破線, 第 2 次までの解が実線である. この場合の数值解からも $\alpha \leq 2.0$ の範 囲で下に凸の曲線となっており, 式 (25) の傾向と一致している. また, ここでも第 1 次の摂動解は $\alpha \leq 0.2$ 程度, 第 2 次の解は $\alpha \leq 0.5$ 程度の範囲で有効であることがわかる.

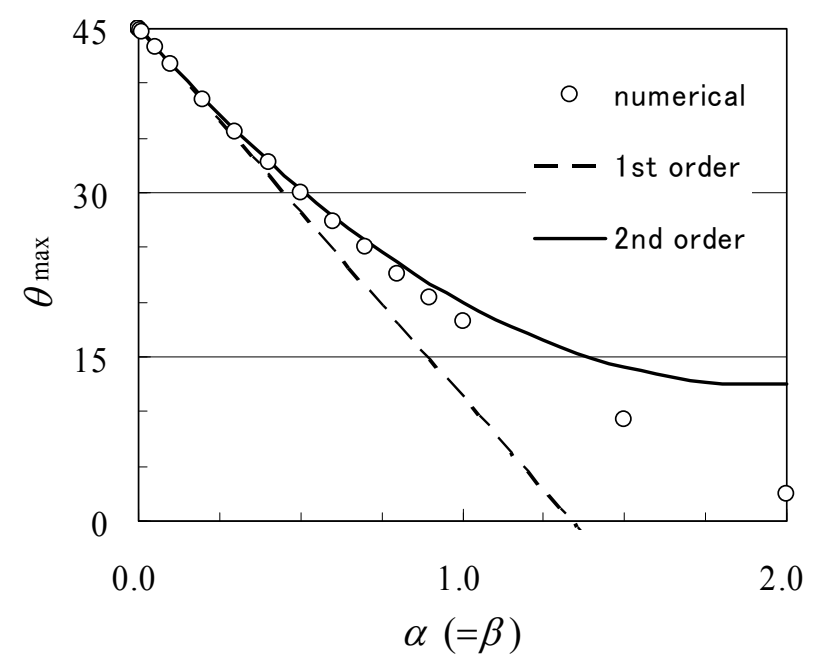

Fig. 3 The effect of linear drag and lift to the maximum projection angle $(\alpha=\beta)$

\section{$4 \cdot 2$ 速度の自乗に比例する空気力}

実際の投射体に働く空気力はその速度の自乗に比例する.ここでは，式（4）に基づいて速度の自乗に比例する 空気力が働く投射体の最大投射角を数值的に求め, その性質を調べた. 数值解を求める方法は 4.1 節と同じ方法 である.

まず，揚力が働かない場合の最大投射角 $\theta_{\max }$ の抵抗による変化を図 4 に示寸. 図中の○が数值解であり，破線 は速度に比例する抵抗に対する数值解（図 1 の○を結んだ線）である. また，数值解から最小自乗法で補間した 以下の 2 次関数を図中に実線で示した.

$$
\theta_{\max }=\frac{\pi}{4}-0.08994 \varepsilon_{D}+0.01826 \varepsilon_{D}^{2}
$$

これらの結果から，自乗抵抗の減少率は線形抵抗より約 $2.6(\approx(\sqrt{2} / 6) / 0.08994)$ 倍ほど小さくなる.このこ とから線形抵抗は自乗抵抗と比べて抵抗を過大に評価寸ることがわかる.また， $\varepsilon_{D} \leq 2.0$ の範囲で自乗抵抗と線形 抵抗ともに下に凸の曲線となっていることも確認できる，そして，この範囲で式（26）による補間は十分な近似 （相関係数 $=0.999921 ）$ を与える.

抵抗のない場合の揚力による最大投射角 $\theta_{\text {max }}$ の変化を図 5 に示す. 図中で用いた記号の意味は図 4 と同じであ る. なお，この場合の数值解の最小自乗補間による近似式は以下となる.

$$
\theta_{\max }=\frac{\pi}{4}-0.28357 \varepsilon_{L}-0.30437 \varepsilon_{L}^{2}
$$




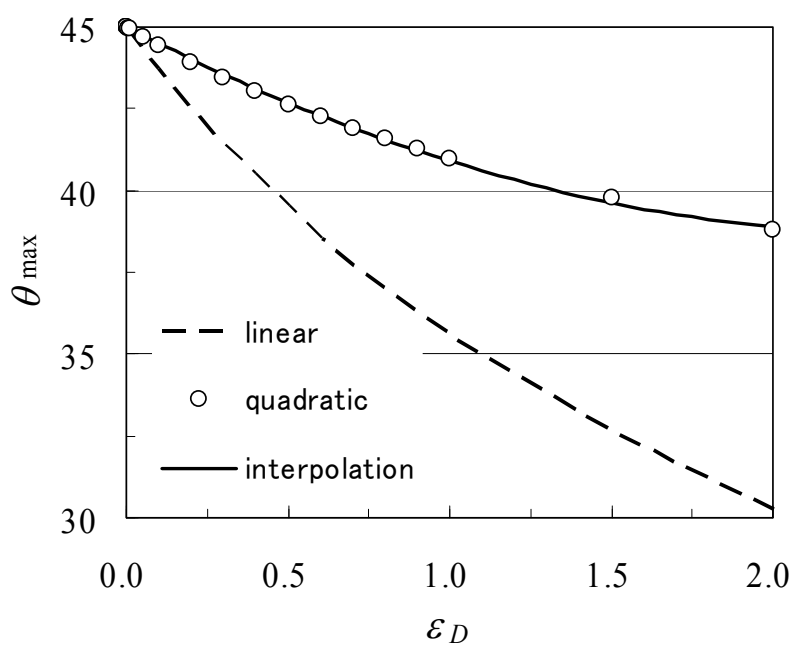

Fig. 4 The effect of quadratic drag to the maximum projection angle without lift $\left(\varepsilon_{L}=0\right)$

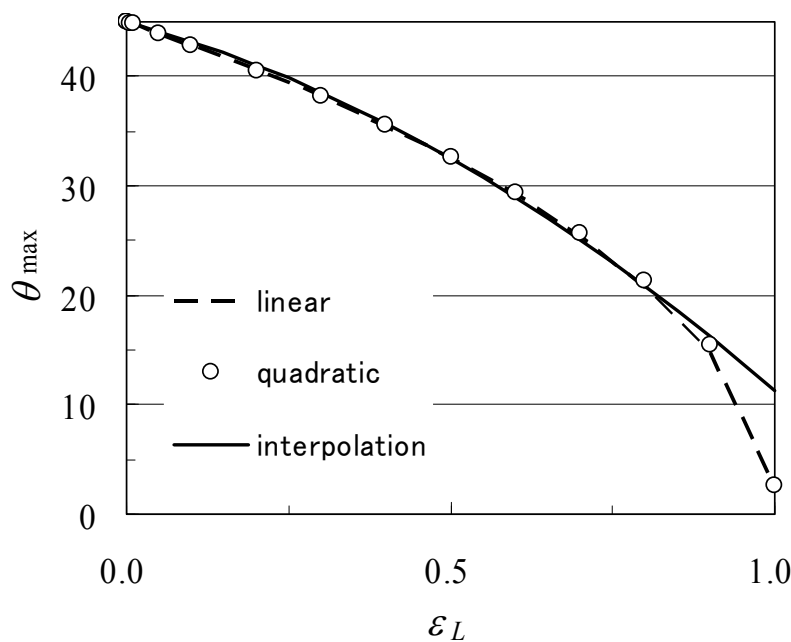

Fig. 5 The effect of quadratic lift to the maximum projection angle without drag $\left(\varepsilon_{D}=0\right)$

Table 1 The difference of the maximum projection angle between linear and quadratic lift (unit: degrees)

\begin{tabular}{c|c|c}
\hline \hline$\varepsilon_{L}(\beta)$ & linear & quadratic \\
\hline 0.01 & 44.79694 & 44.79130 \\
0.1 & 42.90138 & 42.85661 \\
0.5 & 32.55101 & 32.61551 \\
0.9 & 14.75500 & 15.39792 \\
1.0 & 2.64604 & 2.66910 \\
\hline
\end{tabular}

この結果から速度の自乗に比例する揚力と速度に比例する揚力の最大投射角はほぼ一致しており， $\varepsilon_{L} \leq 1.0$ の範 囲で上に凸の曲線になっている. 代表的な $\varepsilon_{L}$ の值に対して, これら 2 種類の揚力に対する最大投射角を比較した 結果を表 1 に示寸．この表からわかるようにその差は最大でも $0.65^{\circ}$ 程度 $\left(\varepsilon_{L}=0.9\right)$ である. また， $\varepsilon_{L}=1.0$ の付 近を除いた範囲 $\left(\varepsilon_{L} \leq 0.8\right)$ で式（27）による補間は十分な近似（相関係数=0.999094）であることもわかる. 
式（26）と（27）の第 1 次の係数から速度の自乗に比例する空気力の場合，最大投射角への揚力の影響は抵抗

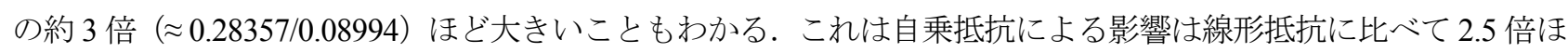
ど小さいのに対して揚力では線形の場合と自乗の場合でその傾きが変わらないことの反映である.

速度の自乗に比例する空気力に対して $\varepsilon_{D}=\varepsilon_{L}$ の場合の結果を図 6 に示す. 図中の記号の意味はこれまでの図と 同じである．また，この場合の最小自乗近似式は

$$
\theta_{\max }=\frac{\pi}{4}-0.41535 \varepsilon_{D}+0.08318 \varepsilon_{D}^{2}
$$

である.この結果から，速度の自乗に比例する空気力の場合にも $\varepsilon_{D} \leq 2.0$ の範囲で最大投射角は下に凸の曲線と なっていることが確認できる．そして，この範囲で式（28）による補間は十分な近似（相関係数=0. 999489）を 与える.

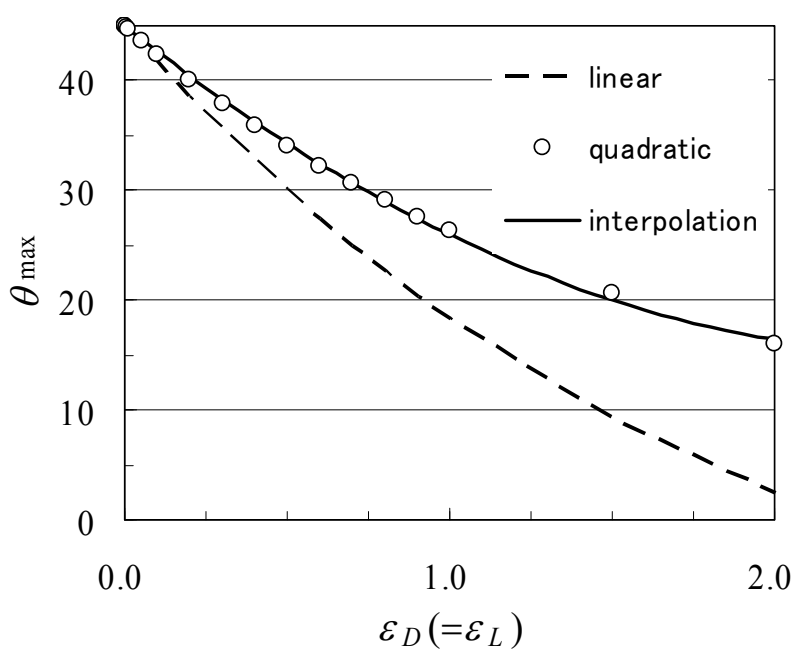

Fig. 6 The effect of quadratic drag and lift to the maximum projection angle $\left(\varepsilon_{D}=\varepsilon_{L}\right)$

\section{5. 結語}

質点で近似した投射体の最大投射角に対する抵抗と揚力の影響について調べた. ここでは抵抗係数と揚力係数 が一定となる空気力に対する最大投射角を考えた．速度の自乗に比例する空気力が働く質点の運動方程式に対し て最大投射角を直接求めることは困難であるため，投射体の速さを運動方程式の空力係数に繰り込むことで速度 に比例する空気力に対する運動方程式を導いた.

この線形化した運動方程式から最大投射角を抵抗係数と揚力係数の第 2 次までの摂動解として陽に求め，その 解から空気力の最大投射角に対寸る定性的効果を明らかにした．さらに，速度の自乗に比例した空気力に対寸る 運動方程式の数值解と比較することで, 線形化によって最大投射角は過小に評価されるが以下に示寸定性的な特 徵は元の方程式の数值解と一致することを確認した.

抵抗および揚力ともに最大投射角を減少させる効果があるが, その影響は抵抗より揚力の方が大きい. 例えば, 速度に比例する場合は 1.5 倍, 速度の自乗に比例する場合は 3 倍程度である. また, 速度および速度の自乗に比 例する空気力のいずれの場合でも，抵抗による減少では最大投射角の曲線は下に凸，揚力では上に凸となる．そ して, 今回の結果から重量抵抗比が 2 以下の範囲で最大投射角は抵抗および揚力係数の 2 次式で十分に近似でき ることもわかった。

なお，揚力と速度の関係にかかわらず最大投射角の揚力に対する関数形は同じになるという結果が得られた. これは本研究によって明らかになった事実であるが，その理由の解明は今後の課題である. 


\section{付録 2 パラメータ関数の摂動公式}

\section{A $\cdot 1$ 展開公式}

独立変数 $\xi$ の 1 変数関数 $f(\xi)$ を考え, これらがともに 2 個の微小パラメータ $\alpha$ と $\beta$ をもつとする. 寸なわち, $\xi=\xi(\alpha, \beta)$ および $f=f(\xi ; \alpha, \beta)$ で表されるとする. 関数 $f$ を $\alpha \beta$ で展開すると

$$
f(\xi ; \alpha, \beta)=f(\xi ; 0,0)+\left.\sum_{n=1}^{\infty} \frac{1}{n !} D^{n} f(\xi ; \alpha, \beta)\right|_{\alpha=\beta=0} \equiv f_{0}(\xi)+\sum_{n=1}^{\infty} f_{n}(\xi)
$$

ただし, $D$ は次式で定義される 2 変数の偏微分演算子である.

$$
D=\alpha \frac{\partial}{\partial \alpha}+\beta \frac{\partial}{\partial \beta} \equiv \alpha \partial_{\alpha}+\beta \partial_{\beta} .
$$

このとき, 第 2 次までの展開項は以下のようになる.

$$
\begin{aligned}
& f_{1}(\xi)=\left.\left(\alpha \partial_{\alpha}+\beta \partial_{\beta}\right) f(\xi ; \alpha, \beta)\right|_{\alpha=\beta=0}=\alpha f_{\alpha}+\beta f_{\beta}, \\
& f_{2}(\xi)=\left.\frac{1}{2}\left(\alpha \partial_{\alpha}+\beta \partial_{\beta}\right)^{2} f(\xi ; \alpha, \beta)\right|_{\alpha=\beta=0}=\frac{1}{2}\left(\alpha^{2} f_{\alpha \alpha}+2 \alpha \beta f_{\alpha \beta}+\beta^{2} f_{\beta \beta}\right) .
\end{aligned}
$$

ただし，簡単のため以下の略号を用いる.

$$
f_{\alpha} \equiv \frac{\partial f}{\partial \alpha}, \quad f_{\beta} \equiv \frac{\partial f}{\partial \beta}, \quad f_{\alpha \alpha} \equiv \frac{\partial^{2} f}{\partial \alpha^{2}}, \quad f_{\alpha \beta} \equiv \frac{\partial^{2} f}{\partial \alpha \partial \beta}, \quad f_{\beta \beta} \equiv \frac{\partial^{2} f}{\partial \beta^{2}} .
$$

同様に, 独立変数 $\xi$ も゚ラメータ $\alpha$ と $\beta$ で展開すると

$$
\xi=\xi(0,0)+\left.\sum_{n=1}^{\infty} \frac{1}{n !} D^{n} \xi(\alpha, \beta)\right|_{\alpha=\beta=0} \equiv \xi_{0}+\sum_{n=1}^{\infty} \xi_{n} .
$$

これより第 2 次までの展開項として以下が得られる.

$$
\begin{aligned}
& \xi_{1}=\left.\left(\alpha \partial_{\alpha}+\beta \partial_{\beta}\right) \xi(\alpha, \beta)\right|_{\alpha=\beta=0}=\alpha \xi_{\alpha}+\beta \xi_{\beta}, \\
& \xi_{2}=\left.\frac{1}{2}\left(\alpha \partial_{\alpha}+\beta \partial_{\beta}\right)^{2} \xi(\alpha, \beta)\right|_{\alpha=\beta=0}=\frac{1}{2}\left(\alpha^{2} \xi_{\alpha \alpha}+2 \alpha \beta \xi_{\alpha \beta}+\beta^{2} \xi_{\beta \beta}\right) .
\end{aligned}
$$

ここでも $\xi$ の偏導関数に関して式(A5)と同様の記号を用いた.

関数 $f$ の第 0 次項 $f_{0}$ に式(A6)の結果を代入して係数ごとにまとめると

$$
\begin{aligned}
f_{0}(\xi) & =f_{0}\left(\xi_{0}+\sum \xi_{n}\right)=f_{0}\left(\xi_{0}\right)+f_{0}^{\prime}\left(\xi_{0}\right) \sum \xi_{n}+\frac{1}{2} f_{0}^{\prime \prime}\left(\xi_{0}\right)\left(\sum \xi_{n}\right)^{2}+\mathrm{O}\left(|D|^{3}\right) \\
& =f_{0}\left(\xi_{0}\right)+f_{0}^{\prime}\left(\xi_{0}\right)\left(\xi_{1}+\xi_{2}\right)+\frac{1}{2} f_{0}^{\prime \prime}\left(\xi_{0}\right)\left(\xi_{1}\right)^{2}+\mathrm{O}\left(|D|^{3}\right) \\
& =f_{0}+\alpha \xi_{\alpha} f_{0}^{\prime}+\beta \xi_{\beta} f_{0}^{\prime}+\frac{1}{2} \alpha^{2}\left(\xi_{\alpha \alpha} f_{0}^{\prime}+\xi_{\alpha}^{2} f_{0}^{\prime \prime}\right)+\alpha \beta\left(\xi_{\alpha \beta} f_{0}^{\prime}+\xi_{\alpha} \xi_{\beta} f_{0}^{\prime \prime}\right)+\frac{1}{2} \beta^{2}\left(\xi_{\beta \beta} f_{0}^{\prime}+\xi_{\beta}^{2} f_{0}^{\prime \prime}\right) \\
& +\mathrm{O}\left(|D|^{\beta}\right) .
\end{aligned}
$$




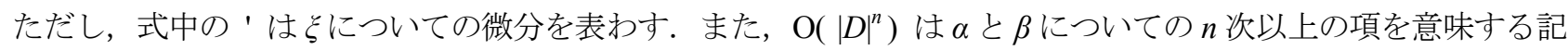
号とする.

同様に，式(A3)の $f_{1}$ と式(A4)の $f_{2}$ を展開するとそれぞれ次式が得られる.

$$
\begin{aligned}
f_{1}(\xi) & =\alpha f_{\alpha}(\xi)+\beta f_{\beta}(\xi) \\
& =\alpha\left(f_{\alpha}\left(\xi_{0}\right)+\alpha \xi_{\alpha} f_{\alpha}^{\prime}\left(\xi_{0}\right)+\beta \xi_{\beta} f_{\alpha}^{\prime}\left(\xi_{0}\right)\right)+\beta\left(f_{\beta}\left(\xi_{0}\right)+\alpha \xi_{\alpha} f_{\beta}^{\prime}\left(\xi_{0}\right)+\beta \xi_{\beta} f_{\beta}^{\prime}\left(\xi_{0}\right)\right)+\mathrm{O}\left(|D|^{3}\right) \\
& =\alpha f_{\alpha}+\beta f_{\beta}+\alpha^{2} \xi_{\alpha} f_{\alpha}^{\prime}+\alpha \beta\left(\xi_{\alpha} f_{\beta}^{\prime}+\xi_{\beta} f_{\alpha}^{\prime}\right)+\beta^{2} \xi_{\beta} f_{\beta}^{\prime}+\mathrm{O}\left(|D|^{\beta}\right), \\
f_{2}(\xi) & =\frac{1}{2}\left(\alpha^{2} f_{\alpha \alpha}(\xi)+2 \alpha \beta f_{\alpha \beta}(\xi)+\beta^{2} f_{\beta \beta}(\xi)\right) \\
& =\frac{1}{2}\left(\alpha^{2} f_{\alpha \alpha}\left(\xi_{0}\right)+2 \alpha \beta f_{\alpha \beta}\left(\xi_{0}\right)+\beta^{2} f_{\beta \beta}\left(\xi_{0}\right)\right)+\mathrm{O}\left(|D|^{3}\right) .
\end{aligned}
$$

これらの結果を式(A1)に代入してパラメータごとにまとめると以下の展開公式が得られる.

第 0 次項 $=f_{0}\left(\xi_{0}\right)$,

$\alpha$ の第 1 次項 $=\xi_{\alpha} f_{0}^{\prime}+f_{\alpha}$,

$\beta$ の第 1 次項 $=\xi_{\beta} f_{0}^{\prime}+f_{\beta}$,

$\alpha$ の第 2 次項 $=\frac{1}{2}\left(\xi_{\alpha \alpha} f_{0}^{\prime}+\xi_{\alpha}^{2} f_{0}^{\prime \prime}+2 \xi_{\alpha} f_{\alpha}^{\prime}+f_{\alpha \alpha}\right)$,

$\beta$ の第 2 次項 $=\frac{1}{2}\left(\xi_{\beta \beta} f_{0}^{\prime}+\xi_{\beta}^{2} f_{0}^{\prime \prime}+2 \xi_{\beta} f_{\beta}^{\prime}+f_{\beta \beta}\right)$,

$\alpha \beta$ の項 $=\xi_{\alpha \beta} f_{0}^{\prime}+\xi_{\alpha} \xi_{\beta} f_{0}^{\prime \prime}+\xi_{\alpha} f_{\beta}^{\prime}+\xi_{\beta} f_{\alpha}^{\prime}+f_{\alpha \beta}$.

\section{A $\cdot 2$ 代数方程式の摂動解公式}

関数 $f(\xi)$ に対する次の方程式の摂動解を考える.

$$
f(\xi)=c \text {. }
$$

ここで $c$ は定数であるが, 微小パラメータ $\alpha$ と $\beta$ は含まないとする.

このとき式(A9)から $\xi_{0}$ に対する以下の方程式が得られる.

$$
f_{0}\left(\xi_{0}\right)=c
$$

次に $\alpha$ と $\beta$ の第 1 次項である式(A10)と式(A11)から

$$
\xi_{\alpha} f_{0}^{\prime}+f_{\alpha}=0, \quad \xi_{\beta} f_{0}^{\prime}+f_{\beta}=0,
$$

がそれぞれ成り立つことから第 1 次の解として次式を得る.

$$
\xi_{\alpha}=-f_{\alpha}\left(\xi_{0}\right) / f_{0}^{\prime}\left(\xi_{0}\right)
$$


$\xi_{\beta}=-f_{\beta}\left(\xi_{0}\right) / f_{0}^{\prime}\left(\xi_{0}\right)$

同様にして式 (A12) から式（A14）の各第2次項に対して

$$
\begin{aligned}
& \xi_{\alpha \alpha} f_{0}^{\prime}+\xi_{\alpha}^{2} f_{0}^{\prime \prime}+2 \xi_{\alpha} f_{\alpha}^{\prime}+f_{\alpha \alpha}=0, \quad \xi_{\beta \beta} f_{0}^{\prime}+\xi_{\beta}^{2} f_{0}^{\prime \prime}+2 \xi_{\beta} f_{\beta}^{\prime}+f_{\beta \beta}=0, \\
& \xi_{\alpha \beta} f_{0}^{\prime}+\xi_{\alpha} \xi_{\beta} f_{0}^{\prime \prime}+\xi_{\alpha} f_{\beta}^{\prime}+\xi_{\beta} f_{\alpha}^{\prime}+f_{\alpha \beta}=0
\end{aligned}
$$

が成り立つ.これらから第 2 次の解として

$$
\begin{aligned}
& \xi_{\alpha \alpha}=-\left(\xi_{\alpha}^{2} f_{0}^{\prime \prime}\left(\xi_{0}\right)+2 \xi_{\alpha} f_{\alpha}^{\prime}\left(\xi_{0}\right)+f_{\alpha \alpha}\left(\xi_{0}\right)\right) / f_{0}^{\prime}\left(\xi_{0}\right), \\
& \xi_{\beta \beta}=-\left(\xi_{\beta}^{2} f_{0}^{\prime \prime}\left(\xi_{0}\right)+2 \xi_{\beta} f_{\beta}^{\prime}\left(\xi_{0}\right)+f_{\beta \beta}\left(\xi_{0}\right)\right) / f_{0}^{\prime}\left(\xi_{0}\right), \\
& \xi_{\alpha \beta}=-\left(\xi_{\alpha} \xi_{\beta} f_{0}^{\prime \prime}\left(\xi_{0}\right)+\xi_{\alpha} f_{\beta}^{\prime}\left(\xi_{0}\right)+\xi_{\beta} f_{\alpha}^{\prime}\left(\xi_{0}\right)+f_{\alpha \beta}\left(\xi_{0}\right)\right) / f_{0}^{\prime}\left(\xi_{0}\right),
\end{aligned}
$$

\section{が得られる.}

これらを用いると方程式(A15)の第 2 次までの摂動解として次式が得られる.

$$
\xi=\xi_{0}+\alpha \xi_{\alpha}+\beta \xi_{\beta}+\frac{1}{2}\left(\alpha^{2} \xi_{\alpha \alpha}+2 \alpha \beta \xi_{\alpha \beta}+\beta^{2} \xi_{\beta \beta}\right)
$$

\section{文献}

(1) de Mestre, N., The mathematics of projectiles in sport (2000), Chap. 8, Cambridge University Press.

(2) Tait, P. G., "Some points in the physics of golf", Nature, Vol. 42, No. 1087 (1890), pp. 420-423.

(3) Bearman, P. W. and Harvey, J. K., "Golf Ball Aerodynamics", Aeronautical Quarterly, May (1976), pp. 112-122.

(4) Linthorne, N. P., "Optimum release angle in the shot put", Journal of Sports Sciences, Vol. 19 (2001), pp.359-372.

(5) Linthorne, N. P., Guzman, M. S., Bridgett, L. A., "Optimum take-off angle in the long jump”, Journal of Sports Sciences, Vol. 23, No. 7 (2005), pp. 703-712.

(6) Tsuboi, K., "A mathematical solution of the optimum takeoff angle in long jump”, Procedia Engineering, Vol. 2, Issue 2 (2010), pp. 3205-3210.

(7) 坪井一洋, “3 自由度投射モデルによる砲丸投げ投法の特徴付け”, 日本機械学会論文集 C 編, Vol. 77, No. 775 (2011), pp. 943-952.

(8) 横山佳之，宮岦武，姫野龍太郎，“ジャイロボールのドラッグクライシス”，ながれ，Vol. 27 (2008), pp. 403-409.

（9）高見圭太, 宮峷武, 姫野龍太郎, “バックスピンする球体に働く負のマグナス力 〜飛翔実験による測定〜”, なが れ, Vol. 28 (2009), pp. 347-356.

(10) 山口哲男, 川松英明, “ゴルフボールの弾道シミュレーション”, シミュレーション, 第 22 巻, 第 1 号 (2003), pp. 21-25.

(11) Parker, G. W., "Projectile motion with air resistance quadratic in the speed", American Journal of Physics, Vol. 45, No. 7 (1977), pp. 606-610.

(12) Chudinov, P. S., "An optimal angle of launching a point mass in a medium with quadratic drag force", Indian Journal of Physics, Vol. 77B, No. 4 (2003), pp. 465-468.

(13) Hayen, J. C., "Projectile motion in a resistant medium, Part I: exact solution and properties", International Journal of Non-Linear Mechanics, Vol. 38 (2003), pp. 357-369.

(14) Synge, J. L. and Griffith, B. A., Principles of Mechanics, 2nd edition (1949), p. 159, McGraw-Hill. 